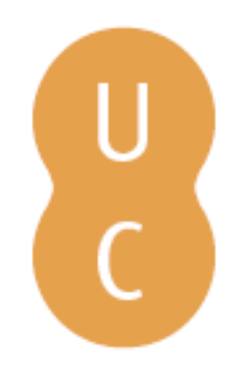

\title{
pompalina
}

\section{Amistad, filantropía y eros en la paideia plutarquea: la Vida de Catón el Viejo}

Autor(es): $\quad$ Ramón Palerm, Vicente M.

Publicado por: Imprensa da Universidade de Coimbra; Centro de Estudos Clássicos e

URL

persistente: URI:http://hdl.handle.net/10316.2/32016

DOI: $\quad$ DOI:http://dx.doi.org/10.14195/978-989-8281-17-3_31

Accessed : $\quad$ 26-Apr-2023 01:51:33

A navegação consulta e descarregamento dos títulos inseridos nas Bibliotecas Digitais UC Digitalis, UC Pombalina e UC Impactum, pressupõem a aceitação plena e sem reservas dos Termos e Condições de Uso destas Bibliotecas Digitais, disponíveis em https://digitalis.uc.pt/pt-pt/termos.

Conforme exposto nos referidos Termos e Condições de Uso, o descarregamento de títulos de acesso restrito requer uma licença válida de autorização devendo o utilizador aceder ao(s) documento(s) a partir de um endereço de IP da instituição detentora da supramencionada licença.

Ao utilizador é apenas permitido o descarregamento para uso pessoal, pelo que o emprego do(s) título(s) descarregado(s) para outro fim, designadamente comercial, carece de autorização do respetivo autor ou editor da obra.

Na medida em que todas as obras da UC Digitalis se encontram protegidas pelo Código do Direito de Autor e Direitos Conexos e demais legislação aplicável, toda a cópia, parcial ou total, deste documento, nos casos em que é legalmente admitida, deverá conter ou fazer-se acompanhar por este aviso.

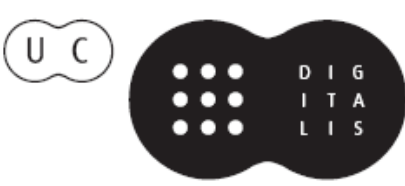




\section{Symposion and Philanthropia in Plutarch}

\section{José Ribeiro Ferreira, Delfim Leão Manuel Troster e Paula Barata Dias (eds.)}

IMPRENSA DA UNIVERSIDADE DE COIMBRA 


\title{
AMISTAD, FILANTROPÍA Y EROS EN LA PAIDEIA PLUTARQUEA: LA VIDA DE CATÓN EL VIEJO ${ }^{1}$
}

\author{
Vicente M. Ramón Palerm \\ Universidad de Zaragoza
}

\begin{abstract}
The present contribution reviews some ethical and emotional criteria that underlie the Life of Cato the Elder in order to determine the real meaning of the Plutarchan paideia. In that sense, Plutarch shows that friendship, philanthropy and eros constitute (in praesentia aut in absentia) a proper manner to describe Cato's personality and education, which must improve as he becomes increasingly familiar with the above-mentioned Greek concepts. Finally, Plutarch seems to maintain that the right use of these concepts has an effect on both the moral and the political education of the statesman.
\end{abstract}

En el estado actual de la investigación plutarquea, podemos desprender ciertas observaciones sobre el programa educativo del biógrafo. Efectivamente, Plutarco presenta el inventario de categorías éticas al servicio de una planificación didáctica, de una paideia político-moral que revierta en beneficio del lector cuya instrucción integral se pretende. $\mathrm{Al}$ respecto, Plutarco traza un diseño de morfología retórica que, por expresarlo con términos acuñados en corrientes de hermenéutica literaria, se articula en torno a un triple eje: emisor, mensaje y receptor. De este modo, el emisor (es decir, el biógrafo como autor) exhibe una retórica moral o retórica de la virtud - expresado en palabras del profesor Stadter - fomentada en el bagaje retórico-escolar del propio Plutarco ${ }^{2}$; el mensaje (o sea, el personaje concretamente implicado) es sometido a una moralización literaria merced a la caracterización que el héroe biografiado experimenta con la educación recibida, con sus acciones y con el ejercicio de la palabra; por último, el receptor (el lector destinatario de la obra) aprehende el legado de una paideia eficaz, la cual contribuirá a sellar la personalidad de un ciudadano - futuro mandatario acaso - capaz, discretamente crítico y cómodamente integrado en el sistema político.

A decir verdad, como ha explicado inteligentemente P. Stadter, el biógrafo expone sus posiciones ético-políticas ante un público de relaciones con el poder frecuentemente estrechas ${ }^{3}$ : este factor y la comprometida situación vivida en época de Domiciano reclamaban, con Trajano, unos modos públicos de mesura, la prudencia del posibilismo histórico, un equilibrio en el fondo $\mathrm{y}$ en la forma de hacer política. El caso es que los nuevos tiempos exigían nuevas soluciones; y Plutarco, vocacionalmente adepto al platonismo medio, propuso con sagacidad categorías doctrinales que conciliaran su adscripción filosófica y el pragmatismo recabado de la nueva política. Ello explica, a la

\footnotetext{
${ }^{1}$ El presente artículo se ha beneficiado del Proyecto HUM 2007-64772, financiado por la DGI española.

${ }^{2}$ P. A. Stadter, 2000.

${ }^{3}$ P. A. Stadter, 2000, pp. 493-4.
} 
postre, que el biógrafo sugiera para el gobernante cabal las virtudes cardinales

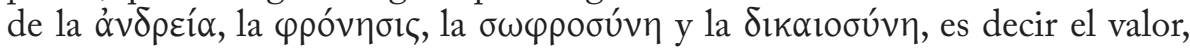
la sensatez, la prudencia y la justicia, criterios morales que ha estudiado modélicamente la profesora F. Frazier'; y explica también que estas virtudes

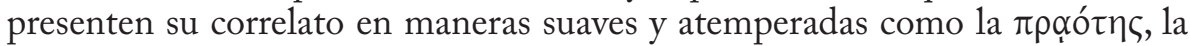

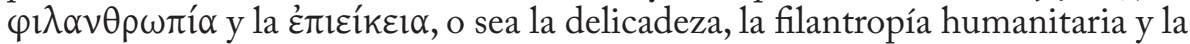
generosidad práctica. En suma, he aquí la adecuación de la forma y el fondo en las virtudes de los héroes biografiados, un principio axiomático que conforma la educación del buen estadista en la arquitectura de la paideia plutarquea y, de paso, prescribe el ennoblecimiento ético-político para el lector amigo ${ }^{5}$.

Por mi parte, no insistiré aquí en el papel, capital sin duda, que Plutarco confiere al sistema educativo en la promoción correcta del individuo ${ }^{6}$. Quiero decir que no procede demorarme en esas virtudes de fondo, por lo demás bien reseñadas, que singularizan (in praesentia o in absentia) la instrucción y condición moral del mandatario correspondiente. Sin embargo, es momento de atenerme a algunas de las virtudes formales que, bien imbricadas, deben complementar y acompasar a las cardinales en la trayectoria de una personalidad definida y paradigmática, como emulación moral para las nuevas generaciones de políticos. Permítaseme que lo exprese de este modo: si la educación académica y convencional se mueve en tres niveles operativos que, como queda dicho, afectan al emisor-autor, al mensaje-personaje y al receptor-lector, nos las vemos ahora con una educación sentimental y concerniente asimismo a los tres niveles citados. Dicho en términos modernos, la inteligencia emocional que también defiende Plutarco constituye una declaración programática y persuasiva que define al autor, caracteriza al personaje y alecciona al lector sobre las bondades de la misma en un doble sentido: como valor intrínsecamente ético y como instrumento de seducción para el arte de la política. Por lo demás, está escrito que, a juicio de Plutarco, el estadista de envergadura debe serlo, sí, y debe parecerlo en el entramado de sus relaciones sociales o afectivas ${ }^{7}$.

Pues bien, con el propósito de ilustrar el tema que nos ocupa, me ha parecido conveniente traer a colación la figura de M. Catón, cuya vida traza Plutarco en una combinación translúcida y sutil de aspectos positivos y negativos sobre la prosopografía del héroe romano. $Y$ es que, dada la técnica compositiva que observamos, esta biografía merece una ponderación exquisita en el quehacer literario de Plutarco ${ }^{8}$. En efecto, una panorámica sobre la estructura de la biografía revela incidencias de interés, ya que la consideración de las categorías ético-emocionales en que nos hemos detenido (la amistad, la filantropía, el eros) perfilan con maestría la semblanza de Catón y destilan

\footnotetext{
${ }^{4}$ F. Frazier, 1996, pp. 177 sqq.

${ }^{5}$ T. Duff, 2007/2008, defiende una lectura de las Vidas en clave filosófico-moral.

${ }^{6} \mathrm{Cf}$. algunos trabajos recientes y significativos sobre la cuestión: A. PÉrez Jiménez, 2002; T. Duff, 2005; S.-T. Teodorsson, 2005.

${ }^{7}$ Cf. A. Pérez Jiménez, 2002.

${ }^{8}$ M. BEck, 2000, p. 20 (y n. 28), indica sin ambages: "The life of the elder Cato certainly ranks as one of Plutarch's best".
} 
las admoniciones pertinentes para las enseñanzas político-morales del lector. Se da la circunstancia añadida de que las observaciones sobre la educación sentimental y la ductilidad de las maneras personales en Catón se adecuan perfectamente a los pormenores de su educación convencional. Veámoslo con un ejemplo singular: una tónica del relato plutarqueo consiste en deslizar la interpretación de que Catón (cuya fama era proverbial en la conciencia colectiva del hombre romano) limó las asperezas de su educación gracias a los contactos que experimentó con el mundo y las letras de Grecia. Sobre el particular, resulta atractivo el pasaje en que Plutarco refiere el cambio de orientación intelectual - en un proceso de mimesis - que observa nuestro personaje tras su encuentro con el pitagórico Nearco (2, 3-6): "En la época en que Fabio Máximo tomó la ciudad de Tarento, Catón, aún muy joven, se hallaba en la campaña bajo sus órdenes. Allí trabó amistad con un tal Nearco, extranjero de la escuela de los pitagóricos, y se apresuró a participar de sus enseñanzas. Una vez que escuchó a este hombre pronunciarse sobre los temas que ha tratado también Platón, quien califica el placer como el mayor señuelo del mal y el cuerpo como la primera desgracia del alma, cuya liberación y purificación se logran mediante la reflexión, que es lo que más la aleja y la disocia de las sensaciones del cuerpo, sintió aún más la inclinación por la austeridad y la continencia. Por lo demás, se dice que comenzó demasiado tarde a instruirse en la cultura griega, que su edad era ya muy avanzada cuando cogió entre sus manos libros en griego y que para el ejercicio de la retórica sacó algo de provecho de Tucídides, y más de Demóstenes. No obstante, su prosa está bastante salpicada de proverbios e historias de los griegos, y en sus máximas y sentencias hay muchas traducciones literales del griego" . Como puede verificarse, este fragmento es de escogida importancia: Catón, que halló en las enseñanzas de Nearco ese espejo modélico para su código ético, pulió las imperfecciones de su instrucción cultural - ya en edad provecta - merced también a las letras griegas ${ }^{10}$. A tenor de lo antedicho, Plutarco contrapone virtudes y defectos en la instrucción cultural de Catón; y

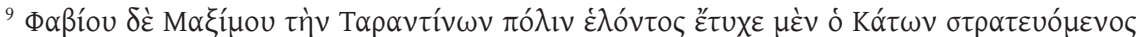

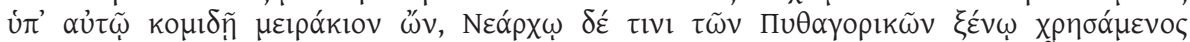

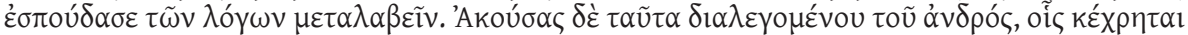

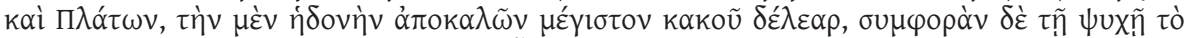

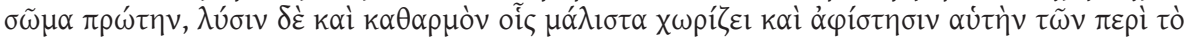

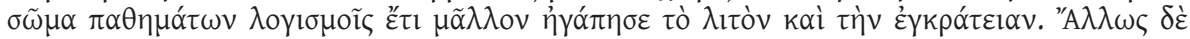

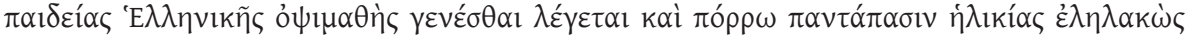

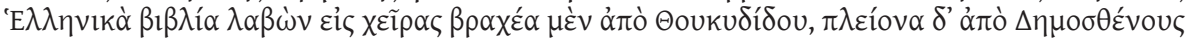

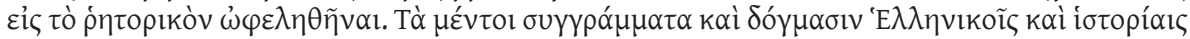

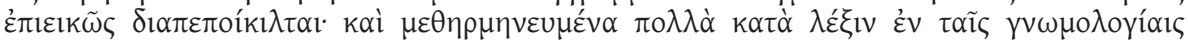
$\tau \varepsilon ́ \tau \alpha \kappa \tau \alpha$ l. La traducción española de los pasajes oportunos procede de L. ConTI, 2003. El texto griego proviene de R. Flacelière \& E. Chambry, Plutarque. Vies, V, Paris, 1969.

${ }_{10}$ Cf. M. Beck, 2000, p. 24. Por lo demás, la aversión por la cultura griega (que Plutarco glosa en el capítulo 23) acompañó a Catón durante buena parte de su vida; por ello, si bien se mira, el pasaje citado redime parcialmente al personaje de su actitud. Para esta anotación y otras implicaciones adicionales del fragmento referido, cf. V. RAMón PALERM, "Plutarco y la biografía política en Grecia: aspectos de innovación en el género", in AA.VV., La biografía como género literario: de la Antigüedad al Renacimiento, Veleia (Anejos). (en prensa).
} 
la presencia del legado griego permite corregir ciertos deslices de la educación convencional en el personaje. Pues bien, del mismo modo, Plutarco alterna aspectos positivos y negativos en la educación sentimental de Catón; y dejará entrever - con nitidez oscilante - que la adecuación del gobernante a esas categorías formales, de señalada impronta griega, contribuye a su perfección ética y al provecho de su actividad política. Así ocurre, verbigracia, con los pasajes en que Plutarco muestra (de manera explícita o implícita) las relaciones que establece Catón con la amistad, la filantropía, el eros $^{11}$. Y debo anticipar que, en líneas generales, el resultado es como sigue: la amistad es divisa fundamental y altamente positiva en el talante de Catón; en segundo lugar, Catón parece escasamente proclive a una conducta filantrópica y, cuando Plutarco menciona detalles al respecto, lo hace de una manera críticamente reservada, negativa en puridad; en última instancia, las actitudes eróticas presentan un curso cambiante en Catón y merecen el elogio cierto o la censura severa, respectivamente, de Plutarco. A continuación, expongo los pasajes representativos sobre las categorías correspondientes.

\section{De la amistad}

$-2,3$ (cf. supra): como ha sido observado, la amistad de Nearco proporciona

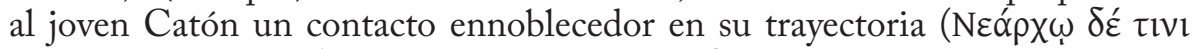

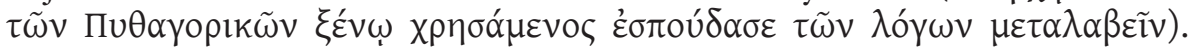
Por añadidura, no debemos soslayar la circunstancia de que el testimonio, el cual transmite Cicerón (Sobre la vejez $[4,10 ; 12,39]$ ), puede responder a un artificio documental, ideado por Cicerón con intención propagandística $\mathrm{y}$ adaptado por Plutarco con un tono moralizante ${ }^{12}$. Obviamente el término implicado, $\varphi \imath \lambda i ́ \alpha$, no consta fehacientemente, pero el contenido amistoso del pasaje resulta incontrovertible. Además, si admitimos que en Plutarco menudea el denominado moralismo implícito - común en el relato general de las semblanzas - por oposición al moralismo explícito que sobresale en las

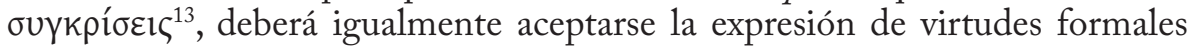
respectivamente implícitas o explícitas.

- 3, 1-4: "Había un patricio, uno de los romanos más influyentes y poderosos, de sorprendente capacidad para apreciar la virtud en el momento

${ }^{11}$ En general, sobre la tradición griega de las categorías que manejamos y la acepción genuina de las mismas en Plutarco, cf. S.-T. Teodorsson, 2007. En todo caso, la utilización de los mencionados conceptos para nuestro trabajo debe entenderse lato sensu, razón por la que hemos renunciado a la expresión de los términos en su versión estrictamente griega.

${ }^{12}$ Cf. J. M. Guzmán Hermida, 2007, p. 68 n. 10. Por otra parte, debe subrayarse que el testimonio sobre enemistad más relevante en esta biografía es relativo a la figura de Escipión el Grande y difiere de otras informaciones histórico-biográficas. Escribe Plutarco $(11,1)$ : "Mientras Catón permanecía todavía en Hispania, Escipión el Grande, que era su enemigo ( $\left.\chi_{\chi} \theta \rho o ́ \varsigma\right)$ y pretendía contrarrestar sus éxitos y asumir los asuntos de Hispania, consiguió obtener aquella provincia como sucesor suyo". Sin embargo, como documenta L. ConTi, 2003, p. 108, n. 279), los datos que consignan Tito Livio $(34,43)$ y Nepote $(C a .2,2)$ discrepan del testimonio plutarqueo; de hecho, niegan que Escipión recibiera entonces la Hispania Citerior.

${ }^{13}$ T. Duff, 2002, especialmente pp. 53 sqq. 
que brota y con buena disposición a alimentarla y encaminarla hacia la fama: Valerio Flaco [...]; ...lo convenció con sus consejos (i.e. a Catón) para que se dedicara a la carrera política en Roma. Así, pues, Catón se dirigió allí y enseguida se granjeó admiradores y amigos con sus discursos de defensa; y mucha fue, además, la honra e influencia que Valerio añadió a su persona. E1 de tribuno militar fue el primer cargo que obtuvo, y más tarde desempeñó el de cuestor. A partir de entonces, gozando ya de luz propia y de popularidad, hizo junto al propio Valerio la carrera hacia las más altas magistraturas y llegó a compartir con él el consulado y, en otra ocasión, la censura" ${ }^{14}$.

- 10, 1: "Designado cónsul junto con Valerio Flaco, íntimo amigo suyo, recibió la provincia que los romanos llaman Hispania Citerior. Allí, mientras sometía a unos pueblos y se granjeaba la amistad de los otros con su diplomacia, cayó sobre él un gran ejército de los bárbaros y corrió el riesgo de ser expulsado deshonrosamente; por ello buscó atraerse la alianza con los vecinos celtíberos"15.

Como puede comprobarse, frente a lo que sucede frecuentemente en los Moralia, los ejemplos en que la amistad comparece no adquieren ribetes de moralización explícita: son aquí aducidos para caracterizar implícitamente el ethos del personaje y manifestar el rendimiento político que el ejercicio de la amistad procura en quienes la cultivan.

\section{De la filantropía}

- 3, 7: "El caso es que Escipión hizo ver en Roma los preparativos de la guerra como anticipo de la victoria y se mostró como alguien alegre durante el tiempo libre que compartía con sus amigos, pero en modo alguno negligente con los asuntos serios e importantes por llevar una vida muelle, con lo cual pudo hacerse a la mar rumbo a la guerra" 16 .

$-5,5$ : $Y$ es que no se debe tratar a los seres animados como sandalias o utensilios, que se tiran cuando están rotos y desgastados por el uso, sino que hay que proponerse ser afable y dulce con ellos, aunque sólo sea por el afán de humanidad"17.

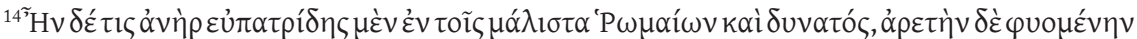

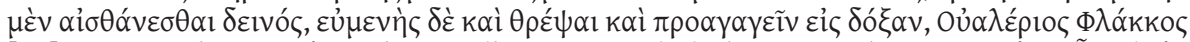

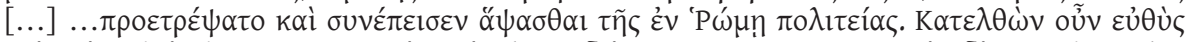

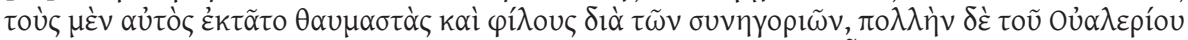

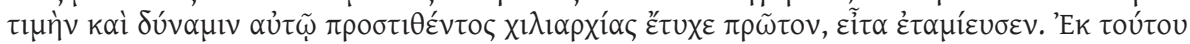

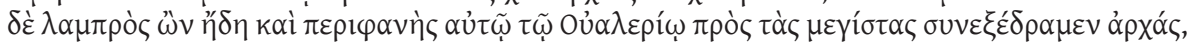

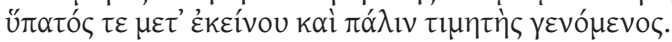

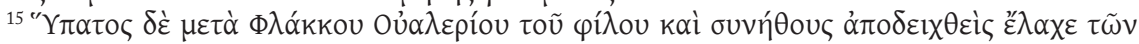

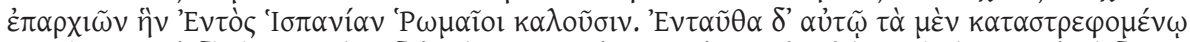

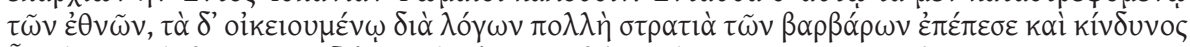

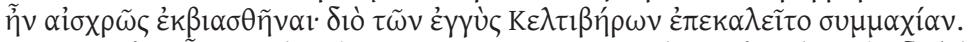

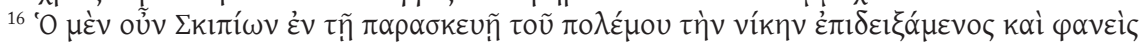

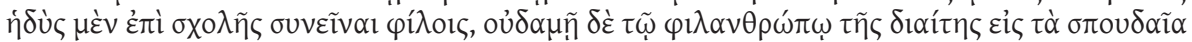

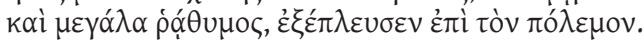

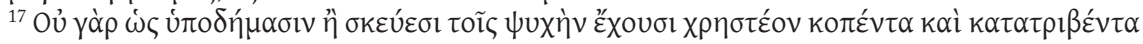


- 22, 2: "Al punto, los jóvenes más amantes de las letras acudieron al encuentro de estos hombres (i.e.filósofos), a quienes escuchaban con admiración. Fue sobre todo el carisma de Carnéades, cuya autoridad era enorme y cuya reputación no era menor que su autoridad, el que atrajo grandes auditorios interesados por los asuntos humanos y el que, como un viento, barrió la ciudad con sus ecos"18.

Los tres pasajes aducidos presentan una importancia nada desdeñable, pese a su aparente y tangencial relación con la figura de Catón ${ }^{19}$. En el primero de ellos, se contraponen a la personalidad austera de Catón los modos de Escipión el Grande (rival y enemigo político del héroe biografiado), cuyo talante desprendido y filantrópico con sus íntimos no empece a la seriedad de la actividad política que despliega. En el segundo fragmento, la sobriedad en exceso cicatera de Catón (quien proponía desechar a los esclavos viejos por inservibles $[\mathrm{cf} .4,5 ; 5,1])$ da paso a cierto comentario del queronense sobre la necesidad de ser indulgente con los seres vivos, en términos absolutos, siquiera por razones humanitarias ${ }^{20}$. En el tercer pasaje, los jóvenes romanos, atraídos por cuestiones de importancia para el ser humano, comparecen con interés a las conferencias de filósofos griegos en Roma; y ello contrasta con el carácter desdeñoso de Catón en relación con la cultura griega y con los efectos de esta sobre las generaciones más jóvenes. En síntesis, da la impresión de que Plutarco confronta las actitudes humanitarias y filantrópicas que personalmente defendía para la comunidad grecorromana ${ }^{21}$ con la indiferencia llamativa de Catón sobre el particular, lo cual parece encerrar una fina crítica implícita al proceder de nuestro personaje mediante una intención que rebasa, seguramente, el puro desliz moral para alcanzar repercusiones de índole política.

\section{Del eros}

- 20,1-4: "Fue también un buen padre, un marido honrado con su mujer y un administrador no desdeñable [...]. Desposó a una mujer más noble que rica, pues creía que, aunque ambos tipos de mujeres eran serias y sensatas, las de buen linaje se avergonzaban ante lo deshonroso y eran más sumisas a sus maridos en lo que atañe a la virtud. Decía que un hombre que golpeaba a su esposa o a su hijo ponía sus manos sobre los seres más sagrados. Le parecía más

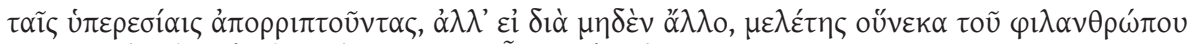

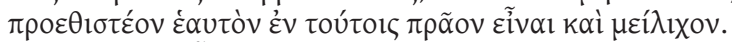

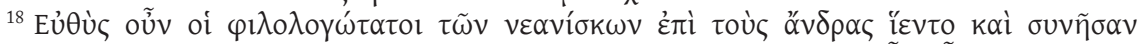

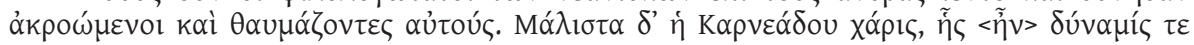

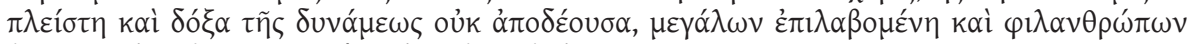

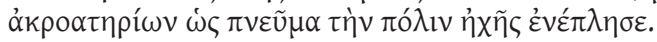

${ }^{19}$ Para un comentario exhaustivo y provechoso de las implicaciones convenientes sobre los pasajes citados (implicaciones de orientación ético-política), remito al estudio de J. M. ${ }^{a}$ CANDAU que consta en el presente volumen ("Filantropía en la Vida de Catón el Viejo").

${ }^{20}$ Esta circunstancia es asimismo detectable en los escritos zoopsicológicos de Plutarco. Cf., en general, la introducción que proporciona G. Santese en L. IngLese \& G. Santese, 1999.

${ }^{21}$ Cf. G. D’Ippolito, 2005, pp. 180-2. 
digno de alabanza ser un buen esposo que un gran senador. En efecto, Catón no admiraba nada del antiguo Sócrates salvo el hecho de que, a pesar de tener una mujer difícil y unos hijos necios, los tratara toda su vida con benevolencia y dulzura. Nacido su hijo, no hubo para él ninguna obligación, salvo las de carácter público, que fuera tan perentoria que le impidiera ayudar a su mujer mientras bañaba y envolvía en pañales a su hijo"22.

- 24, 1: "Es evidente que...Catón no quedó libre de la venganza divina, pues perdió tanto a su esposa como a su hijo. Pero él, que era de constitución robusta y se mantenía fuerte y vigoroso, resistió durante muchísimo tiempo, de modo que, aun siendo ya anciano, tenía con frecuencia contacto sexual con alguna mujer y, en contra de lo que conviene a su edad, contrajo de nuevo matrimonio..." 23 .

- 6, 1-3 (бúүкрıбıৎ): "El matrimonio del propio Catón, sin embargo, impropio tanto de su honor como de su edad, infundió a este respecto sospechas importantes y serias. En efecto, el que un anciano de tanta edad y con un hijo ya adulto...despose a la hija de un sirviente suyo...no está nada bien. Tanto si lo hizo buscando placer como si fue por vengarse del asunto con la hetera, la acción y su motivo son por igual vergonzosos. El argumento al que acudió con tono irónico ante su hijo no era cierto, pues si hubiera querido traer al mundo hijos tan nobles como éste, debería haber reparado en ello desde un principio y haber contraído matrimonio legal en lugar de contentarse con cohabitar con una mujer ilegítima y compartida mientras pasó inadvertido y, una vez que fue descubierto, hacer suegro suyo a quien era más fácil de convencer, y no a aquel con quien hubiera resultado más honroso crear lazos familiares" ${ }^{24}$.

Es perceptible que la indicación de los lances erótico-amorosos en la Vida de Catón ofrece una perspectiva doble y palmariamente opuesta sobre la actitud del

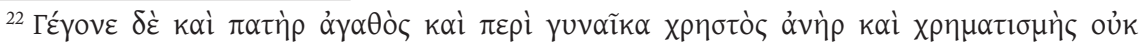

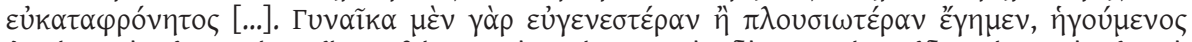

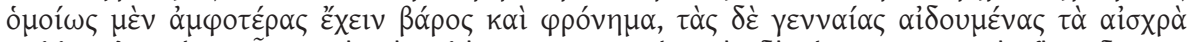

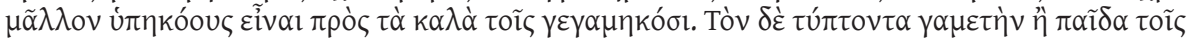

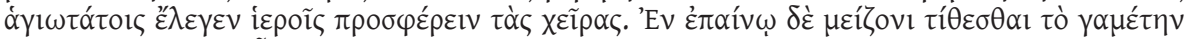

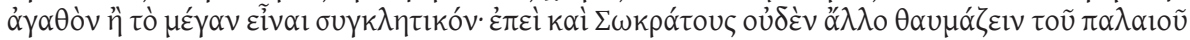

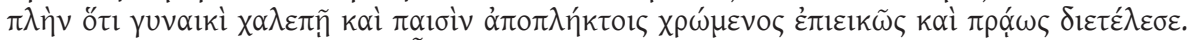

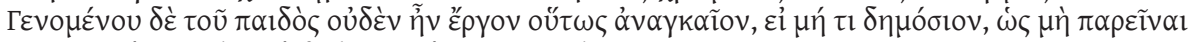

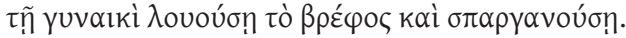

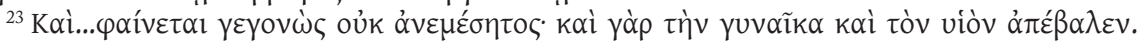

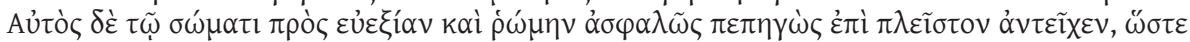

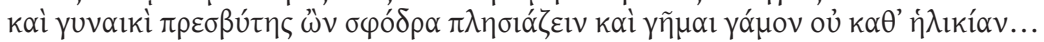

${ }_{24} \ldots \alpha$...

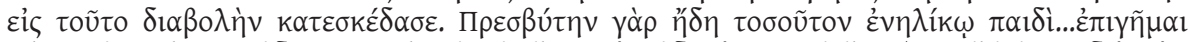

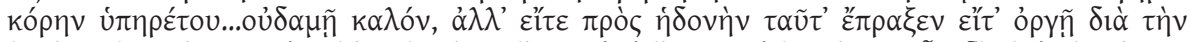

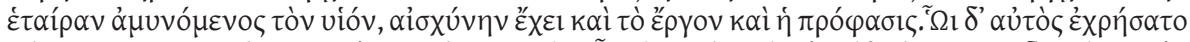

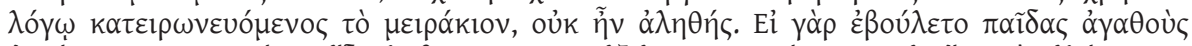

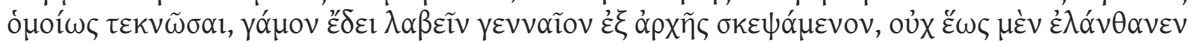

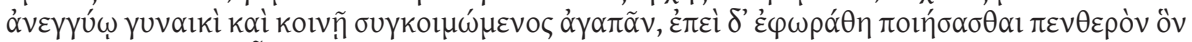

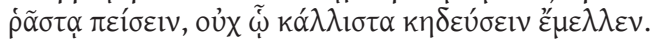


estadista. Advertimos una caracterización implícita en los dos primeros pasajes

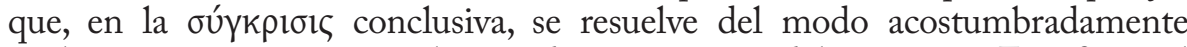
explícito por cuanto atañe al segundo matrimonio del personaje. En efecto, el primer pasaje muestra a un Catón amante de su esposa y corresponsable en la unidad conyugal, un Catón que comparte las tareas paterno-filiales y observa una reciprocidad cotidiana en el curso de su relación marital. Plutarco se prodiga en elogios sobre la figura de Catón, ya que el matrimonio se conduce a la manera que el de Queronea defiende en su Erótico, donde priman la concordia y la responsabilidad doméstica de los esposos prácticamente en pie de igualdad ${ }^{25}$. No obstante, la opinión de Plutarco se modifica radicalmente en lo concerniente al segundo matrimonio de Catón. Y es que Plutarco censura ahora tanto la ratificación del matrimonio perse (considerando la edad avanzada del mandatario) cuanto las razones presuntas del mismo, acaso motivadas por el hecho de que Catón mantenía relaciones sexuales, en su propia casa y de modo indisimulado, con una concubina joven y de moralidad laxa; el caso es que la muchacha paseaba por la casa impúdicamente a la vista del propio hijo de Catón, lo cual tensa la convivencia entre el padre, el hijo y la novia de este. Pues bien, Catón resuelve de forma urgente concertar matrimonio con la hija de uno de sus esclavos para zanjar el asunto y tal vez dar un golpe de autoridad paterna ${ }^{26}$.

Para concluir: la moralización implícita que menudea en la Vida de Catón se ve motivada, en buena medida, por la destreza cultural y las virtudes cardinales del personaje merced a su pericia y contactos tardíos con la paideia griega. De modo simétrico, Plutarco desliza la concepción de que las virtudes formales, la educación sentimental, la inteligencia emocional de Catón se hallan caracterizadas por la ausencia o presencia respectiva de categorías inherentes, asimismo, al orbe heleno. He aquí una reflexión tamizada con que Plutarco perfila el talante de Catón, claro está; pero se trata también de una reflexión con que el biógrafo trasciende la pura defensa de ciertos valores afectivos-morales, anejos al personaje, para el ennoblecimiento del lector $y$, en última instancia, para el sustento de una paideia henchida de aristas ético-políticas al servicio del estadista incipiente en un mundo civilizador, grecorromano, globalizado.

\section{Bibliografía CITADA}

Beck, M., "Anecdote and the Representation of Plutarch's Ethos", in L. VAN Der Stockт (ed.), Rhetorical Theory and Praxis in Plutarch. Acta of the IV International Congress of the I.P.S. (Leuven, July 3-6), LouvainNamur, 2000, pp. 15-32.

${ }^{25}$ Cf. las oportunas reflexiones de M. Valverde, 2003. Cf. asimismo J. Beneker, 2008, particularmente p. 698.

${ }^{26}$ Cf. 24, 2-7, donde Plutarco refiere los pormenores correspondientes sobre el asunto. 
Beneker, J., "Plutarch on the Role of Eros in a Marriage", in A. G. Nikolaidis (ed.), The Unity of Plutarch's Work. Moralia Themes in the Lives, Features of the Lives in the Moralia, Berlin-New York, 2008, pp. 689-99.

Contr, L., Plutarco. Vidas de Aristides y de Catón, Madrid, 2003.

D’Ippolito, G., "Filantropia, ellenocentrismo e polietnismo in Plutarco", in A. Pérez Jiménez \& F.Titchener (eds.), Historical and Biographical Values of Plutarch's Works. Studies devoted to Professor Philip A. Stadter by the International Plutarch Society, Málaga-Logan, 2005, pp. 17996.

Duff, t., Plutarch's Lives. Exploring Virtue and Vice, Oxford, 2002.

"Education in Plutarch's Themistokles", in M. Jufresa et AL. (eds.), Plutarc a la seva època. Paideia $i$ societat. Actas del VIII Simposio español sobre Plutarco, (Barcelona, 6-8 de Noviembre, 2003), Barcelona, 2005, pp. 553-60.

"Plutarch's readers and the moralism of the Lives", Ploutarchos, n.s. 5 (2007/2008) 3-18.

Flacelière, R. \& Chambry, E., Plutarque. Vies, V, Paris, 1969.

Frazier, F., Histoire et morale dans les Vies parallèles de Plutarque, Paris, 1996.

Guzmán Hermida, J. M., Plutarco. Vidas Paralelas. IV, Madrid, 2007.

Inglese, L. \& Santese, G., Plutarco. Il cibarsi di carne, Napoli, 1999.

Pérez Jiménez, A., "Exemplum: the paradigmatic education of the ruler in the Lives of Plutarch", in P. A. Stadter \& L. VAN Der Stockt (eds.), Sage and Emperor. Plutarch, Greek Intellectuals, and Roman Power in the Time of Trajan (98-117 A.D.), Louvain, 2002, pp. 105-14.

"La elocuencia como instrumento político en las Vidas paralelas", $C F C$, 12 (2002) 253-70.

Ramón Palerm, V., "Plutarco y la biografía política en Grecia: aspectos de innovación en el género", in AA.VV., La biografía como género literario: de la Antigüedad al Renacimiento, Veleia (Anejos). (en prensa).

Stadter, P. A., "The rhetoric of virtue in Plutarch's Lives", in L. VAN DER Sтоскт (ed.), Rhetorical Theory and Praxis in Plutarch. Acta of the IV International Congress of the I.P.S. (Leuven, July 3-6), Louvain-Namur, 2000, pp. 493-510.

Teodorsson, S.-T., "El programa de Plutarco para la conducta social”, in M. Jufresa et al. (eds.), Plutarc a la seva època. Paideia $i$ societat. Actas del VIII Simposio español sobre Plutarco (Barcelona, 6-8 de Noviembre, 2003), Barcelona, 2005, pp. 659-64. 
"Four terms of friendly emotion in Plutarch: $\Phi \imath \lambda \alpha v \theta \rho \omega \pi i ́ \alpha, \varphi \imath \lambda i ́ \alpha$, है $\rho \omega \varsigma$,

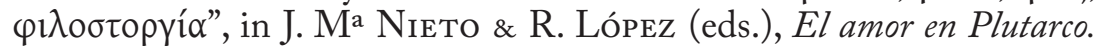
Actas del IX Simposio español sobre Plutarco (28-30 Septiembre, 2006), León, 2007, pp. 187-97.

Valverde, M., "Amor y matrimonio en el Erótico de Plutarco", in J.M. a Nieto (ed.), Logos Hellenikós. Homenaje al Profesor Gaspar Morocho Gayo, León, 2003, pp. 441-54. 